\title{
Moodle LMS: Positive and Negative Aspects of Using Distance Education in Higher Education Institutions
}

\section{Moodle LMS: aspectos positivos y negativos del uso de la educación a distancia en instituciones de educación superior}

\author{
Evgeny Evgenievich Egorov \\ Kozma Minin Nizhny Novgorod State Pedagogical University, Nizhny Novgorod, Russia \\ ORCID: 0000-0003-0082-3712 \\ Maria Petrovna Prokhorova \\ Kozma Minin Nizhny Novgorod State Pedagogical University, Nizhny Novgorod, Russia \\ ORCID: 0000-0003-0357-4213 \\ Tatiana Evgenievna Lebedeva \\ Kozma Minin Nizhny Novgorod State Pedagogical University, Nizhny Novgorod, Russia \\ ORCID: 0000-0001-9672-1395 \\ Olga Aleksandrovna Mineeva \\ Kozma Minin Nizhny Novgorod State Pedagogical University, Nizhny Novgorod, Russia \\ ORCID: 0000-0002-5669-3497

\section{Svetlana Yevgenyevna Tsvetkova} \\ Kozma Minin Nizhny Novgorod State Pedagogical University, Nizhny Novgorod, Russia \\ ORCID: 0000-0002-0333-2444
}

Received 09-08-20 Revised 10-10-20 Accepted 12-11-20 On line 03-06-21

*Correspondencia

Email: rector@rea.ru

\section{Citar como:}

Evgenievich, E., Petrovna, M., Evgenievna, T., Aleksandrovna, O., \& Yevgenyevna, S. (2021). Moodle LMS: Positive and Negative Aspects of Using Distance Education in Higher Education Institutions, Propósitos y Representaciones, 9(SPE2), e1104. http://dx.doi.org/10.20511/pyr2021.v9nSPE2.1104

(c) Universidad San Ignacio de Loyola, Vicerrectorado de Investigación, 2021. 


\section{Summary}

The Moodle learning management system (LMS) is currently successfully integrated into the educational activities of higher education. This article discusses the peculiarities of Moodle LMS and elements of training courses in it. The research aims at highlighting the assessments of opportunities and disadvantages of the Moodle LMS from the positions of undergraduate students and teachers in the quarantine conditions and before them. The research was conducted at the Kozma Minin Nizhny Novgorod State Pedagogical University in 2018/2019 and 2019/2020 academic years at the Faculty of Management, Social and Technical Services. The research involved teachers and first to fourth year full-time undergraduate students. The analysis of both positive and negative feedback from undergraduate students and teachers about working in a normal learning model and in self-isolation has been presented. Interactive elements of the learning environment have been considered and the research results of students' attitudes to its various elements have been described. The methods and potential use of Moodle by means of different electronic devices have been explored, and the usage frequency of these devices during quarantine has been analyzed. The analysis of negative feedback about the students' and teachers' work in the system during the pandemic has been given. Control methods in the Moodle environment, testing, and authors' control methods have been studied. In the survey, the respondents evaluated the basic functions of the Moodle LMS, popular in teaching, gave a description of the advantages and disadvantages of this system and evaluated potential areas of system development in educational practice of the University. The conclusions have been made about the need to implement blended learning using the Moodle LMS, which combines various types of distance and classroom work for students.

Keywords: Higher Education, Undergraduate Student, E-Learning, Distance Learning, Blended Learning, COVID-19, Information And Educational Environment, Learning Management System, Moodle.

\section{Resumen}

El sistema de gestión del aprendizaje de Moodle (LMS) se encuentra actualmente integrado con éxito en las actividades educativas de la educación superior. Este artículo analiza las peculiaridades de Moodle LMS y los elementos de los cursos de formación en él. La investigación tiene como objetivo resaltar las valoraciones de oportunidades y desventajas del LMS de Moodle desde las posiciones de estudiantes de pregrado y docentes en las condiciones de cuarentena y ante ellos. La investigación se realizó en la Universidad Pedagógica Estatal Kozma Minin Nizhny Novgorod en los años académicos 2018/2019 y 2019/2020 en la Facultad de Administración, Servicios Sociales y Técnicos. La investigación involucró a profesores y estudiantes de pregrado a tiempo completo de primero a cuarto año. Se ha presentado el análisis de la retroalimentación tanto positiva como negativa de estudiantes de pregrado y profesores sobre el trabajo en un modelo de aprendizaje normal y en autoaislamiento. Se han considerado elementos interactivos del entorno de aprendizaje y se han descrito los resultados de la investigación sobre las actitudes de los estudiantes hacia sus diversos elementos. Se han explorado los métodos y el uso potencial de Moodle a través de diferentes dispositivos electrónicos y se ha analizado la frecuencia de uso de estos dispositivos durante la cuarentena. Se ha realizado el análisis de la retroalimentación negativa sobre el trabajo de los estudiantes y profesores en el sistema durante la pandemia. Se han estudiado los métodos de control en el entorno Moodle, las pruebas y los métodos de control de los autores. En la encuesta, los encuestados evaluaron las funciones básicas del LMS de Moodle, popular en la docencia, dieron una descripción de las ventajas y desventajas de este sistema y evaluaron áreas potenciales de desarrollo del sistema en la práctica educativa de la Universidad. Las conclusiones se han extraído sobre la necesidad de implementar el aprendizaje mixto utilizando el LMS de Moodle, que combina varios tipos de trabajo a distancia y presencial para los estudiantes. 
Palabras clave: Educación superior, Estudiante de pregrado, E-Learning, Educación a distancia, Aprendizaje mixto, COVID-19, Entorno de información y educación, Sistema de gestión del aprendizaje, Moodle.

\section{Introduction}

The results of digitalization of modern education were extremely popular in the unique and forced conditions of distance learning caused by self-isolation due to the spread of the COVID19 virus, which forever changed the Russian educational system (Blinov et al., 2020). For educational organizations, this was manifested in a sharp increase in the need for developed integrated information and educational environments that combined the educational function with educational management process (Gruzdeva \& Tukenova, 2019; Vaganova et al., 2020), support for educational, economic, research, project, and cultural activities (Arkhipova et al., 2018). Expanding the capabilities of information and educational environments of universities allows getting access to educational resources (educational programs, projects, electronic publications, etc.) remotely (Tukenova et al., 2019), conducting and recording all forms of the educational process results (Amandu et al., 2013), including certification, schedule of the educational process, electronic portfolio, etc. (Atef \& Medhat, 2015). In the context of distance learning, educational organizations have become more open, which is embodied not only in the availability of information and full information support of the educational process, but also in the rapid development of open distance courses, mobile applications, etc. (Tolsteneva et al., 2020).

It can be stated that the growing need for developed information and educational environments and effective distance solutions in the context of potential quarantine will lead to even more active development of distance education in all its formats. Currently, the most common educational process management system used in Russian educational organizations is Moodle LMS, which provides great opportunities for organizing the educational process and is well-tested in practice (Aikina \& Bolsunovskaya, 2020; Mineeva et al., 2018). In the current context of the pandemic, Moodle LMS took on the greatest load, as teachers and students were deprived of the opportunities for face-to-face communication being the basis of traditional learning. As a result, the advantages and disadvantages of the Moodle LMS have become more obvious, and the issues related to the efficiency of this system in blended and distance learning formats have become of scientific interest.

At present, the problems of using Moodle LMS in higher education have been sufficiently studied; however, the use of this system in the educational process raises new, previously unknown issues, in particular, the possibility of supplementing this system with other systems and teaching tools, the organization of training in an "inverted" format, etc. (Murphy, 2020). These studies are highly important for the methodological support of teachers who use Moodle LMS in their daily educational activities, therefore, they do not lose their relevance.

\section{Literature Review}

The analysis of works devoted to the use of Moodle LMS in higher education suggests that this system has been widely applied in Russia and abroad (Lyashenko \& Frolova, 2013; Oproiu, 2015). Among the advantages of Moodle LMS, most researchers and practitioners note:

- wide opportunities for developing students' independence, responsibility, and activity;

- the use of various information resources that develop skills to work with information; 
- the ability to create individual educational paths, personal portfolios and databases of students' academic performance, achievements, etc.;

- the opportunity for creation of new knowledge, experience exchange, consulting.

Multiple studies of Russian and foreign authors have been devoted to analyzing the research opportunities, advantages and disadvantages of Moodle LMS. According to the analysis of the works, most of them focus either on the general functionality of this educational system (Shurygin \& Krasnova, 2019) or highlight the experience of developing specific ecourses (Samerkhanova \& Balakin, 2020; Wen \& Yang, 2020). Foreign studies on this issue consider the attitude of teaching staff to the transition to distance learning (Colis \& Moonen, 2001), systematize the skills of teachers working with such systems (Garrison \& Vaughan, 2008), sum up the overall results of distance learning using Moodle LMS (Oproiu, 2015).

Research that reveals and evaluates the features of using Moodle LMS in a completely distance learning format is clearly not enough, since the experience gained by teachers has not yet been comprehended, systematized and generalized. It can be stated that the use of Moodle LMS in a completely remote format allowed understanding its functionality in a new way, identifying drawbacks and opportunities. This statement is a previously unresolved part of the problem of using Moodle LMS in higher education, since further development of distance learning is possible only if all participants in the educational process have the opportunity to fully use the functionality of Moodle LMS in achieving educational goals.

This research is aimed at presenting the results of a comparative study of teachers' and students' attitude to the opportunities and disadvantages of Moodle LMS during the quarantine and before it. This comparison will allow better evaluating the existing functionality of the system under the study, clarifying its advantages and disadvantages, and suggesting directions for its more effective use in practice.

The research objectives are as follows:

1. Clarifying the purpose of using Moodle LMS in the educational process before and during the quarantine;

2. Evaluating the advantages and disadvantages of Moodle LMS in distance learning;

3. Evaluating the Moodle LMS tools that were most effectively used in both situations;

4. Defining directions for more effective application of Moodle LMS in remote conditions.

\section{Methods}

The research was conducted in 2018/2019 and 2019/2020 academic years at Kozma Minin Nizhny Novgorod State Pedagogical University (the Russian Federation). It was based on theoretical (selection and analysis of literature on the research topic) and empirical methods (filling in questionnaire in the Google-form) of analysis; statistical technology (survey results processing). Participation in the survey was voluntary and anonymous.

The research had two stages.

At the first stage of the research in the 2019/2020 academic year, the survey was conducted to assess students' and teachers' ability to use the Moodle LMS functionality as an 
auxiliary tool in the traditional learning model. The second stage of the research was conducted at the end of the 2019/2020 academic year after 3 months of distance learning in conditions of forced quarantine and self-isolation. The respondents answered the questionnaire questions again, having behind them the experience of using Moodle LMS as the main educational system and lack of personal communication with other participants in the educational process.

At the first stage of the research, the questionnaire questions related to the goals of using this system, its advantages and disadvantages, as well as its prospects. At the second stage, the questionnaire was supplemented with a question concerning the change in attitude to this LMS after the experience of complete distance learning.

The participants in the survey were 74 undergraduate students and 37 professors of Kozma Minin Nizhny Novgorod State Pedagogical University.

Table 1. Characteristics of the respondents

\begin{tabular}{|c|c|c|}
\hline Feature & Number & Percent (\%) \\
\hline \multicolumn{3}{|c|}{ Undergraduate students (74 participants) } \\
\hline \multicolumn{3}{|c|}{ ( } \\
\hline Economics & 18 & 24.3 \\
\hline Teacher training & 40 & 54.1 \\
\hline Management & 16 & 21.6 \\
\hline \multicolumn{3}{|l|}{ Age } \\
\hline 17 & 4 & 5.4 \\
\hline 18 & 26 & 35.1 \\
\hline 19 & 25 & 33.8 \\
\hline 20 & 11 & 14.8 \\
\hline 21 & 7 & 9.5 \\
\hline 22 & 1 & 1.4 \\
\hline \multicolumn{3}{|l|}{ Gender } \\
\hline male & 14 & 18.9 \\
\hline female & 60 & 81.1 \\
\hline \multicolumn{3}{|l|}{ Academic year } \\
\hline 1 & 18 & 24.3 \\
\hline 2 & 35 & 47.3 \\
\hline 3 & 12 & 16.2 \\
\hline 4 & 9 & 12.2 \\
\hline \multicolumn{3}{|c|}{ Teaching staff (37 participants) } \\
\hline \multicolumn{3}{|l|}{ Position } \\
\hline lecturer / senior lecturer & 6 & 16.2 \\
\hline associate professor & 28 & 8.1 \\
\hline professor & 3 & 75.7 \\
\hline \multicolumn{3}{|l|}{ Gender } \\
\hline male & 16 & 43.2 \\
\hline female & 21 & 56.8 \\
\hline
\end{tabular}

The data obtained were compared, analyzed and processed using descriptive statistics.

\section{Results}

At first, the goals of using Moodle LMS before the quarantine (i.e., in the situation when the LMS complemented the traditional educational process) and during the quarantine (in the 
situation when Moodle LMS became the main tool for implementing the educational process) were compared. The results are presented in Figure 1.

placement and use of materials for practical work placement / studying theoretical material consulting
information exchange
reporting on training tracking the progress of students communication

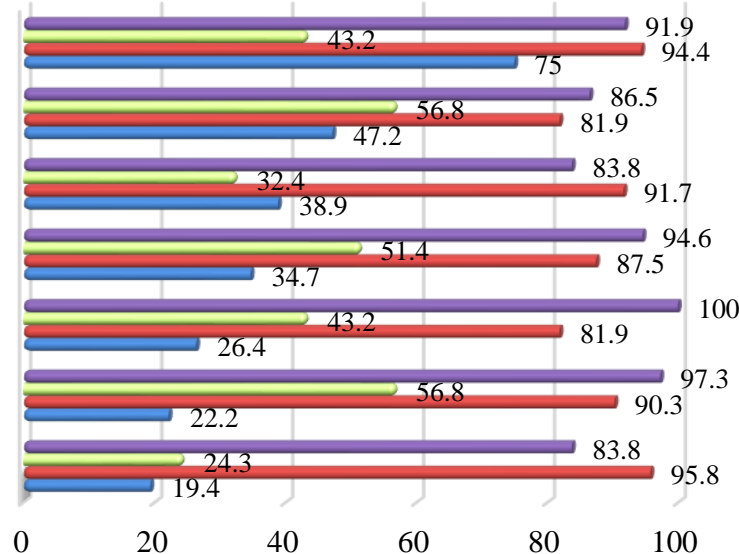

$\square$ Teachers during the distance learning period, $\%$ $\square$ Students during the distance learning period, $\%$

$\square$ Teachers before the distance learning period, \% $\square$ Students before the distance learning period, $\%$

Figure 1. Goals of Moodle LMS Employment

As can be seen in the graph, the goals of Moodle LMS employment for both teachers and students in distance learning had changed. In the context of traditional learning, the most popular feature of Moodle LMS for all categories of users was the placement and use of materials for practical work (as indicated by $43.2 \%$ of teachers and $75 \%$ of students). Students rated the value of Moodle LMS for studying theoretical material lower than teachers $(47.2 \%$ vs. $56.8 \%$ ), which was due to the wide opportunities of searching for information in the free access. For teachers in the conditions of traditional training, tracking the progress of students $(56.8 \%)$ and reporting on training (43.2\%) were important, which indicated the high importance of automating functions for systematizing and storing information about the educational process (however, the same option was evaluated lower among students - only $26.4 \%$ indicated it). Such function of Moodle LMS as consulting in traditional and blended learning was in demand only for $32.4 \%$ of teachers and $38.9 \%$ of students, and communication through this system was carried out only among $24.3 \%$ of teachers and $19.4 \%$ of students.

Comparing the responses to the same question during the distance learning period, significant changes in the use of this system were found. This primarily affected the communication function (the share of teachers using the Moodle LMS communication features and capabilities increased from $24.3 \%$ to $83.8 \%$, the share of students increased from $19.4 \%$ to $95.8 \%$ ), and the use of the information exchange function increased among teachers (from $51.4 \%$ to $94.6 \%$ ) and students (from $34.7 \%$ to $87.5 \%$ ). This was due to the replacement of interpersonal communication with virtual communication, as well as due to an increase in the number of students who strived to perform academic work exactly in accordance with the task of the teacher. The Moodle LMS functionality for generating and storing reports has also become more valuable, with $56.8 \%$ more teachers and $55.5 \%$ more students accessing it.

Next, it was found out how the attitude of participants to Moodle LMS had changed during distance learning (Fig. 2). 


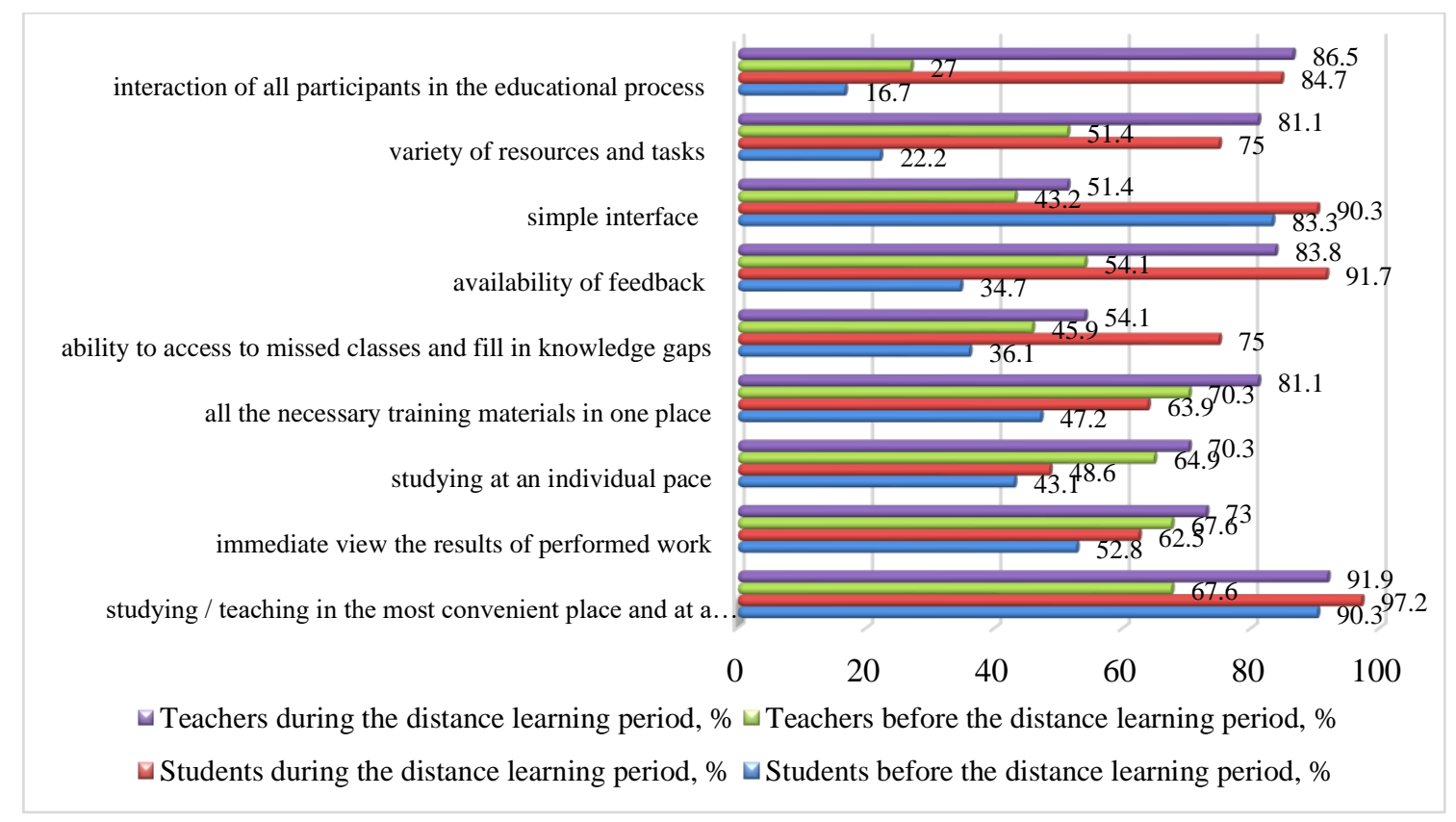

Figure 2. Assessment of Moodle LMS Advantages

The analysis of respondents' answers to the question about the advantages of Moodle LMS showed that during traditional education, the main advantage for the majority of students $(90.3 \%)$ "was the ability to study in the most convenient place and at a convenient time", then $83.3 \%$ of students noted the simple interface as an advantage of the system. In the third place was the ability to immediately view the results of performed work, which was highlighted by $52.8 \%$ of the surveyed students. For $47.2 \%$ of respondents, it was important to have all the necessary training materials in one place. Slightly less than half of the respondents considered it important to study at an individual pace (43.1\%), as well as highly evaluated the possibility to have access to missed classes and complete the necessary tasks (36.1\%). The interaction of all participants in the educational process $(16.7 \%)$, the variety of resources and tasks $(22.2 \%)$, and the availability of feedback $(34.7 \%)$ were less important before the quarantine and the transition to an online format. During the forced distance learning, students reconsidered such advantages of Moodle LMS as the availability of feedback ( $57 \%$ increase), the variety of resources and tasks (52.8\% increase) and the interaction of all participants in the educational process $(68 \%$ increase), as well as the ability to fill in knowledge gaps (38.9\% increase). Such results were explained, in the authors' opinion, by limited opportunities for consultations and greater need for clear understanding of the content and management aspects of the educational process.

Teachers who were cautious about evaluating the benefits of Moodle LMS before distance learning also changed their perception of the positive characteristics of this LMS after gaining experience in online teaching. Thus, the most valuable perspective of the teachers used to be the availability of all required materials in one system (70.3\%) and the opportunity to teach in a convenient location and at a convenient time (67.6\%). Whereas during distance learning among the advantages of Moodle LMS teachers confidently pointed out the opportunity to teach in a convenient location and at a convenient time (91.9\%), the interaction of all educational process participants $(86.5 \%)$, the availability of feedback with students $(83.8 \%)$, the ability to upload various resources and tasks, and all necessary training materials $(81.1 \%)$.

As a result of the distance learning experience, the attitude of survey participants to the disadvantages of Moodle LMS had also changed (Fig. 3). 


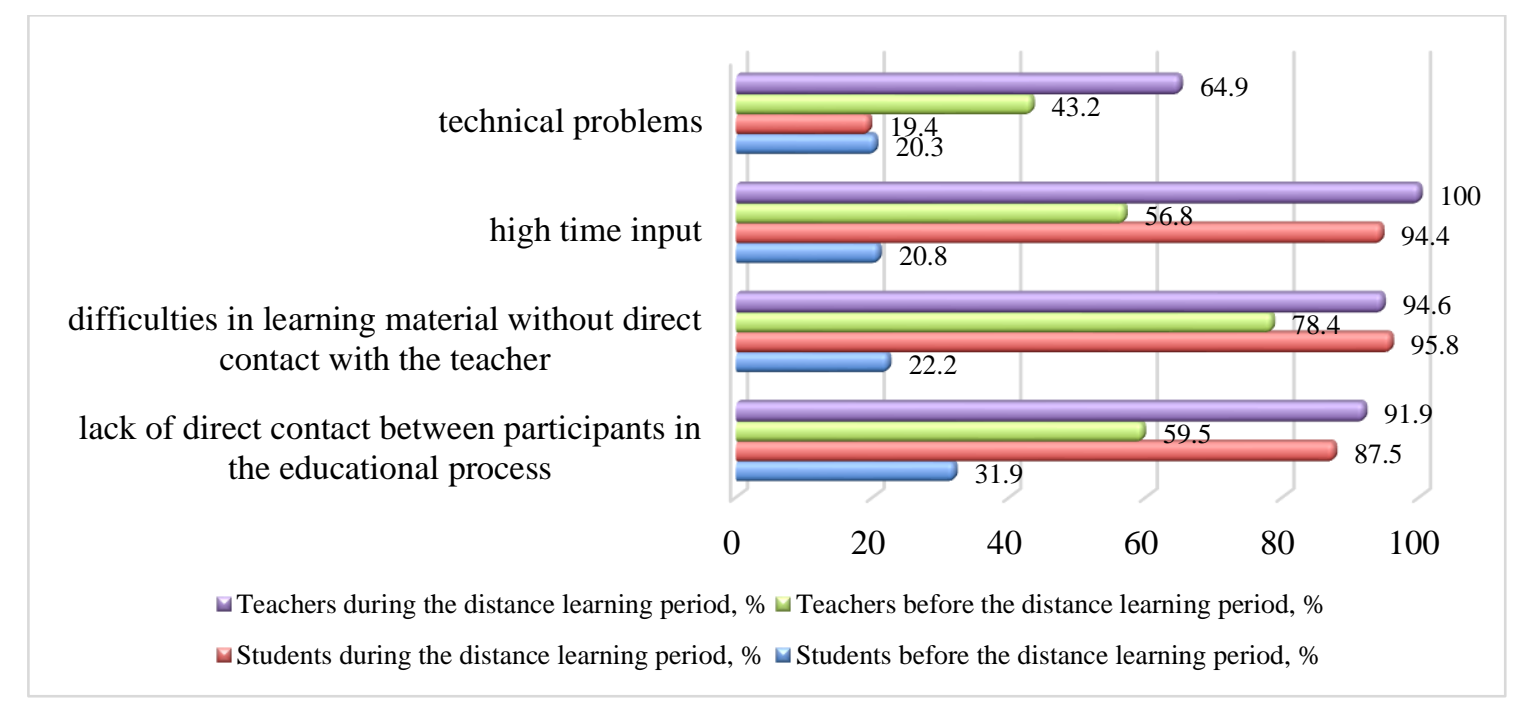

Figure 3. Assessment of Moodle LMS Disadvantages

Before the implementation of distance learning, the main disadvantages of this system for students were "lack of direct contact between participants in the educational process" (31.9\%), "difficulties in learning material without direct contact with the teacher" $(22.2 \%)$, "high time input" (20.8\%). While studying in the distance learning format, such disadvantages as "difficulties in learning material without direct contact with the teacher" and "long time spent on learning material" became more significant for students (the number of students increased by $73.6 \%$ ). The obtained data showed that many students needed help and support in organizing their educational activities, and the timing of assignments and other reporting was important for them.

As for teachers, the major drawback was the difficulty of students' learning without direct contact with the teacher (78.4\%), as well as the lack of direct contact between participants in the educational process $(59.5 \%)$. During the full distance work, such disadvantages as high time input (it was noted by $100 \%$ of teachers) and difficulties in mastering the material without direct contact with the teacher $(94.6 \%)$ came to the forefront.

The question of evaluating the efficiency of the main interactive elements of Moodle LMS, which were most often used in the educational process, was important for the research. To do this, respondents were asked to evaluate the effectiveness of the elements "Assignment", "Lesson", "Quiz", "Wiki", "Forum" and "Glossary" providing the study and assimilation of educational material, assessment, feedback and communication on a 1 to 10-point scale (Fig. 4). 


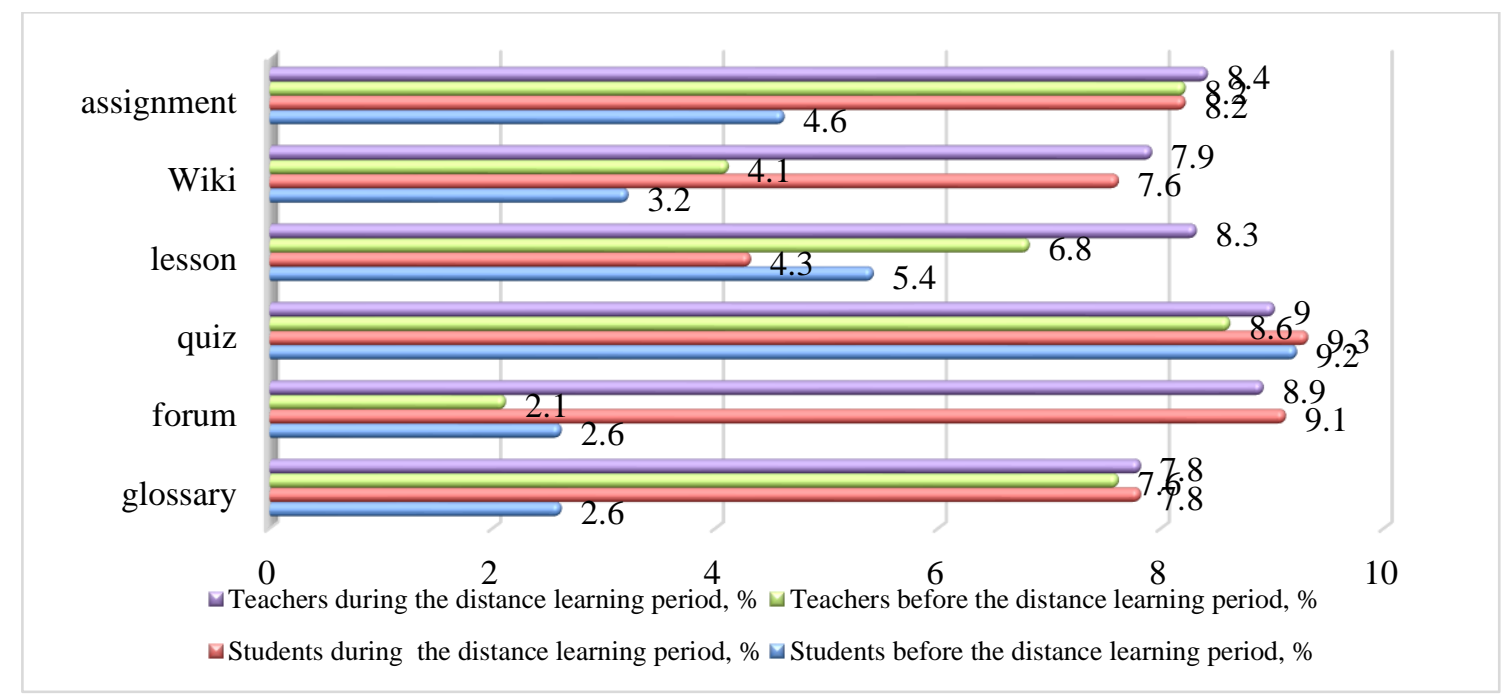

Figure 4. Assessment of Efficacy of Tools in Moodle LMS

The research results demonstrate that both teachers and students considered testing to be the most effective means of achieving educational results both during traditional training (8.6 and 9.2 points) and during online training ( 9 and 9.3 points). A significant increase was observed in the assessing the importance of the "Forum" element. If during the traditional training students rated the importance of this element at 2.6 points, and teachers - at 2.1 points, then during distance learning it was rated by students at 9.1 points, and by teachers - at 8.9 points. This fact is easily explained by the fact that "Forum" as a means of communication is very important for participants of the educational process in a distance learning format. As for the "Assignment" element, its importance was rated consistently high by teachers $(8.2$ and 8.4 points). Students' recognition of this element's efficiency increased significantly during the distance learning period (the average point increased from 4.6 to 8.2). During the distance learning, the attitude to the "Wiki" element had changed on the part of all participants in the educational process. The importance of "Wiki" as a tool that allowed students working in groups to create collaborative learning products during self-isolation had grown significantly. The average rating of this element among students increased from 3.2 to 7.6, and among teachers - from 4.2 to 7.9. The element "Lesson" was rated lower by students than by teachers. Such results were observed both during traditional training and during distance learning. This can be explained by the fact that students used other sources of information, such as online libraries, reference books, databases, etc., in addition to the material published in electronic educational complexes. The "Glossary" element, being also an important learning tool, was always highly rated by teachers (7.6 and 7.8 points). As for students, this element had become particularly important during distance learning (the average score had increased from 2.6 to 7.8). In the authors' opinion, such a high rating was given by students during distance learning, since the "Glossary" had a number of features that made it easier to study the course at a time when the educational load had significantly increased.

At the end of the research, a question was asked whether the attitude of teachers and students to Moodle LMS and its capabilities had changed during and after the three-month distance learning experience. When asking this question, it was assumed that the situation of total distance learning allowed all the participants of the educational process to become more familiar with the functionality of this LMS, as well as to evaluate and understand the possibilities of replacing personal communication with virtual one (Fig. 5). 


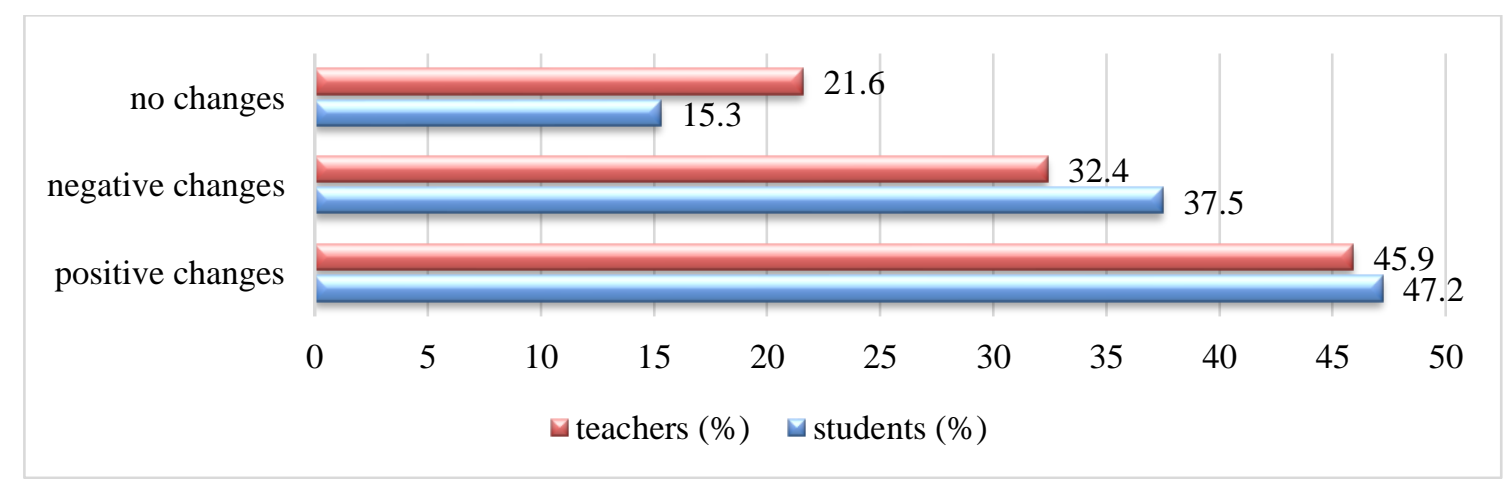

Figure 5. Change of participants' attitude toward Moodle LMS during e-learning

The results do not leave any doubt that the attitude of the majority of respondents, both students and teachers, to the Moodle LMS functionality had changed. It is important to note that there were positive dynamics of changes: the number of students whose attitude to Moodle LMS had changed for the better exceeded the number of teachers $-47.2 \%$ and $45.9 \%$, respectively. The authors assume that this result might correlate with the technical challenges of working in Moodle LMS, which were noted by many teachers.

A change in attitude for the worse was recorded in $32.4 \%$ of the surveyed teachers and $37.5 \%$ of students. Despite the fact that the number of survey participants whose attitude had changed for the worse was less than the number of participants whose attitude had changed for the better, this fact could not be ignored. In the authors' opinion, in the future it is necessary to study the factors that caused negative attitude to this LMS in more detail. However, it can be assumed that the result of the negative attitude of respondents to the Moodle LMS functionality could have been negative attitude to the conditions of distance learning and self-isolation in which all participants of the educational process found themselves. As a result, there was a lack of live communication and contact between students and teachers, a large amount of educational material being taken out for independent study, and large time input. As for teachers, technical challenges might have negatively affected them because of the low level of digital literacy, as well as an increase in the time spent on placing educational content in the electronic environment and checking students' assignments. $21.6 \%$ of teachers and $15.3 \%$ of students did not change their attitude to the Moodle LMS functionality during distance learning.

\section{Conclusion}

Based on the research results, a number of conclusions can be formed regarding the experience of distance learning using Moodle LMS.

1. During the rapid transition to distance learning, the Moodle LMS has become the main means of learning, the effectiveness of which has been proven by the results of the research.

2. The survey results have shown that during distance learning, the value of Moodle LMS as a means of learning, communication and interaction of all participants of the educational process has increased. The proof is the fact that such elements of the system as "Quiz" and "Assignment" were rated highly in any form of training, but when evaluating the effectiveness of the" Forum" and "Wiki" elements, the leap was observed during distance learning, since these elements provided participants with communication, discussion and teamwork. 
3. All participants of the educational process have better mastered the Moodle LMS functionality in distance learning. Many of Moodle LMS functions have become more popular these are the functions related to communication, reporting, tracking progress, and organizing collaboration. Thus, many functions, that normally constitute communication in the traditional educational process, have been replaced by Moodle LMS.

4. Distance learning has significantly increased the transparency of the educational process, increased the ability of outside (including administrative) control over the activities of all its participants. The openness of the Moodle LMS has led to more stringent requirements for deadlines, criteria, organization and self-organization.

5. The educational process in completely remote format using Moodle LMS is more difficult and stressful for all its participants. In this regard, the issues related to both the choice of content and changes in the laws, principles and tools required for the remote format are the most relevant today.

6. A natural result of the research is the preference of the vast majority of students and teachers for blended learning, which involves the combination of various forms and methods of work, both distance and classroom.

The contribution of the research to the study of the problems of using Moodle LMS consists in specifying the goals, advantages and disadvantages of Moodle LMS during distance learning, which contributes to the development of the practice of using such systems in education.

\section{References}

Aikina, T.Y., \& Bolsunovskaya, L.M. (2020). Moodle-based learning: Motivating and demotivating factors. International Journal of Emerging Technologies in Learning, 15(2), 239-248. https://doi.org/10.3991/ijet.v15i02.11297

Amandu, G.M., Muliira, J.K., \& Fronda, D.C. (2013). Using moodle e-learning platform to foster student self-directed learning: Experiences with utilization of the software in undergraduate nursing courses in a Middle Eastern university. Procedia-Social and Behavioral Sciences, 93, 677-683.

Arkhipova, M.V., Zhulina, E.V., \& Shutova, N.V. (2018). Information society and the educational process. Problems of modern pedagogical education, 59-1, 56-59.

Atef, H., \& Medhat, M. (2015). Blended learning possibilities in enhancing education, training and development countries: a case study in graphic design courses. TEM-Journal, 4(4), 358-365.

Blinov, V.I., Sergeev, I.S., \& Esenina, E.Ju. (2020). Sudden distance learning: the first month of emergency. Vocational education and labor market, 2(41), 6-33.

Colis, B., \& Moonen, J. (2001). Flexible learning in a digital world: Experiences and expectations. London: Kogan-Page.

Garrison, D.R., \& Vaughan, N.D. (2008). Blended learning in higher education: Framework, principles, and guidelines. San Francisco: Jossey-Bass.

Gruzdeva, M.L., \& Tukenova, N.I. (2019). Analysis of the current state of research and development in the construction of information and educational environments of higher educational institutions. Vestnik of Minin University, 7(2), 1-14. https://doi.org/10.26795/95/2307-1281-2019-7-2-1

Lyashenko, M.S., \& Frolova, N.H. (2013). Learning management system as an effective means of e-learning. World Applied Sciences Journal, 27(13A), 100-104. 
Mineeva, O.A., Prokhorova, M.P., Borshtchevskaya, Yu.M., \& Terekhina, A.Ye. (2018). Students' perception of advantages and disadvantages of using LMS Moodle. Azimuth of Scientific Research: Pedagogy and Psychology, 7(4), 162-165.

Murphy, M.P.A. (2020). COVID-19 and emergency eLearning: Consequences of the securitization of higher education for post-pandemic pedagogy. Contemporary Security Policy, 41(3), 492-505. https://doi.org/10.1080/13523260.2020.1761749

Oproiu, G.C. (2015). A study about using e-learning platform (Moodle) in university teaching process. Procedia-Social and Behavioral Sciences, 180, 426-432.

Samerkhanova, E.K., \& Balakin, M.A. (2020). Training managers of professional educational programs for work in the digital environment of the university. Vestnik of Minin University, 8(2), 4. https://doi.org/10.26795/2307-1281-2020-8-2-4

Shurygin, V.Yu., \& Krasnova, L.A. (2019). Blended learning in the system of training of teachers' qualification. Baltic Humanitarian Journal, 8(1), 324-328.

Tolsteneva, A.A., Gruzdeva, M.L., Katkova, O.V., Prokhorova, O.N., \& Lagunova, M.V. (2020). Organizational and Technical Conditions for the Implementation of Educational Programs of the University Using Open Online Courses of the National Platform for Open Education. Lecture Notes in Networks and Systems, 73, 473-483.

Tukenova, N.I., Ramazanov, R.G., Gruzdeva, M.L., Baydildinov, T.Z., \& Naubetova, S.A. (2019). Methodology for developing e-learning courses in IT education. International Journal of Innovative Technology and Exploring Engineering, 8(10), 3614-3616.

Vaganova, O.I., Lebedeva, T.Ye., Prokhorova, M.P., Smirnova, Zh.V., \& Shkunova, A.A. (2020). Pedagogical support of the educational and information environment. Espacios, 40(2), 21-28.

Wen, J., \& Yang, F. (2020). Use of Moodle in College English Language Teaching (Reading and Listening) in China: A Narrative Review of the Literature. International Journal of Information and Education Technology, 10(6), 466-470. 